\title{
INFLUENCE OF NITROGEN ON POTATO PRODUCTIVITY AND NUTRIENT USE EFFICIENCY
}

\author{
Antons Ruža*, Ilze Skrabule**, and Aija Vaivode** \\ * Institute of Agrobiotechnology, Latvia University of Agriculture, Lielā iela 2, Jelgava LV-3001, LATVIA; \\ Antons.Ruza@llu.Iv \\ ** State Priekuli Plant Breeding Institute, Zinātnes iela 1a, Priekuḷi LV-4126, LATVIA; \\ ilze.skrabule@priekuliselekcija.Iv
}

Communicated by Aldis Kārkliṇ̌s

\begin{abstract}
Yield and quality of potato depend on nutrient availability in soil, especially regarding nitrogen. Nitrogen $(N)$ is a very dynamic plant nutrient and its uncontrolled application can considerably raise the price of agricultural production. If $N$ is insufficiently utilised by plants environmental pollution can occur. The aim of the study was to investigate efficiency of nitrogen fertiliser use by potato. The field trials were carried out at the State Priekuli Plant Breeding Institute from 2009 till 2012. Nine fertilisation variants were applied: no fertilisation; PK dose to provide potato yield of $40 t$ $\mathrm{ha}^{-1}$; and the remaining seven variants with a PK dose plus plus increasing $\mathrm{N}$ amount from 30 to $210 \mathrm{~kg} \mathrm{ha}^{-1}$. The results of the four-year experiment years indicated that an increase in nitrogen fertilizer rate up to $N 120 \mathrm{~kg} \mathrm{ha}^{-1}$ increased the potato yield. Nitrogen fertilizer rates should be applied depending on potato variety and planned use of the grown potato crop. Tuber nitrogen content increased with nitrogen fertilizer level from $1.09 \%$ in the treatment NOPK up to $1.53 \%$ in treatment N120, and practically remained at that level in treatments with higher $N$ application levels. Nitrogen content in potato foliage was twice as high as that in tubers and continuously increased with the $N$ amount applied, and particularly with higher nitrogen fertilizer rates of N150-210. In regard only to tuber yield, the $N$ utilization coefficient at a nitrogen fertilizer rate up to $N 120$ was on average 0.60 . A further increase in nitrogen rate reduced the $N$ utilization coefficient with each successive step.
\end{abstract}

Key words: fertilization, nitrogen, uptake, efficiency, potassium.

\section{INTRODUCTION}

Potato is a very significant agricultural crop in the economy of Latvia. In 2011, the area of potato production was 29600 ha and average yield was $16.8 \mathrm{t} \mathrm{ha}^{-1}$. The total potato production of about 500 thousand tonnes covers the selfconsumption of Latvia's population (Anonīms, 2012).

Crop yield and quality mostly depend on the availability of nutrients in soil. Nitrogen $(\mathrm{N})$ is a very dynamic plant nutrient. Its uncontrolled application can considerably raise the price of agricultural production, and under increased rates of $\mathrm{N}$ insufficient utilisation by plants may result in environmental pollution (Moreno et al., 2003). Potato fields quite often receive too high amounts of $\mathrm{N}$ fertiliser, which, combined with a shallow root system, creates high risk of $\mathrm{N}$ leaching losses (Neumann et al., 2012). According to the EU Council Directive 91/676/EEC of 12 December 1991 with regard to water protection from pollution caused by residual $\mathrm{N}$ of agricultural origin, excessive fertiliser use endangers the environment, and therefore restrictions are needed to limit contamination by residual $\mathrm{N}$ fertiliser in soil. Maintaining high crop yields with minimum nutrient losses to the environment is and will continue to be a significant challenge to the potato producers (Westerman, 2005).

Nitrate $\left(\mathrm{NO}_{3}\right)$ is the most frequently documented contaminant in potato production areas. Studies in areas with differing weather and soil conditions and cropping practices showed that low fertiliser recovery, high residual fertilizer $\mathrm{N}$ and the risk of $\mathrm{NO}_{3}$ loss to environment were often associated with inadequate use of fertilizers. The application of fertilisers above a threshold level often proves inefficient for production purposes creates risks of nitrate and phosphorus pollution of groundwater (Ierna et al., 2011; Westerman, 2005).

Several $\mathrm{N}$ fertilisation rates have been advised as optimal for potato production. In some European countries and the USA that have a potato growth cycle of 4-5 months, the recommended $\mathrm{N}$ fertilisation rates vary from 70 to $330 \mathrm{~kg}$ $\mathrm{ha}^{-1}$, and the most economically efficient rates from 147 to $201 \mathrm{~kg} \mathrm{ha}^{-1}$ (Fontes et al., 2010). The application of me- 
dium levels of fertilisers $\left(100,50\right.$ and $150 \mathrm{~kg} \mathrm{ha}^{-1} \mathrm{~N}, \mathrm{P}_{2} \mathrm{O}_{5}$ and $\mathrm{K}_{2} \mathrm{O}$, respectively) has been suggested for irrigated potato growing areas, combining it with medium water supply (Ierna et al., 2011). Researchers in the Czech Republic advise a fertilisation rate of $140 \mathrm{~kg} \mathrm{ha}^{-1}, 63 \mathrm{~kg} \mathrm{ha}^{-1}$ and $186 \mathrm{~kg}$ $\mathrm{ha}^{-1} \mathrm{~N}, \mathrm{P}_{2} \mathrm{O}_{5}$ and $\mathrm{K}_{2} \mathrm{O}$, respectively, as the optimal for tuber yield above $30 \mathrm{t} \mathrm{ha}^{-1}$. It has been observed that a $\mathrm{N}$ dose of $120 \mathrm{~kg} \mathrm{ha}^{-1}$ applied in the form of mineral fertiliser is the most environmentally acceptable $\mathrm{N}$ fertilisation rate for potato (Srek et al., 2010). The application of $130 \mathrm{~kg} \mathrm{ha}^{-1} \mathrm{~N}$ by fertigation (fertilization together with irrigation) is sufficient for potato (Darwish et al., 2006).

Low $\mathrm{N}$ supply will not only result in lower yield but will also reduce tuber size due to reduced leaf area and early defoliation (Vos, 1995; Goffart et al., 2008;). Higher N fertilisation rates have positive effect on plant growth parameters, and they increase tuber number and yield. Also, higher $\mathrm{N}$ rates also are associated with more foliage and consequently promote photosynthetic action, and hence more translocatation to tubers (Kumar et al., 2007).

An increased potato yield is mostly associated with N application, whereas phosphorus $(\mathrm{P})$ and potassium $(\mathrm{K})$ without $\mathrm{N}$ have insignificant impact on yield (Baniuniene and Zekaite, 2008). However, excess $\mathrm{N}$ fertilization leads to dry matter yield in other parts of the plant than the tubers, promoting excessive stolon and leaf growth; both leaf maturation and tuber differentiation are delayed and the length of tuber bulking period, yield and tuber dry matter are reduced (Vos, 1995; Goffart et al., 2008). Studies have shown that efficiency of agronomic $\mathrm{N}$ use decreases linearly with increased $\mathrm{N}$ dose (Darwish et al., 2006; Kumar et al., 2007; Fontes et al., 2010).

Fertilisation rates that meet crop $\mathrm{N}$ requirements, including all sources of input in the complete soil nitrogen balance, are the most effective way of reducing the amount of soil nitrate at harvest, minimising the long-term environmental impact of excess nitrate (Peralta and Stockle, 2001; Ozturk et al., 2010). N must normally be added to fertilizer to achieve maximum economic potato yields. Its efficiency may be substantially improved if it is applied as close as possible to the actual plant growth needs (Westermann, 2005).

Usually, $\mathrm{N}$ nutrition or fertilisation recommendations suggest one recommended rate of supply at the beginning of growing season. The required external input in soil depends on crop growth or actual demand for $\mathrm{N}$, and on supply from sources other than external input, both of which are strongly affected by weather in the season (Vos, 2009). Potato crop needs for $\mathrm{N}$ are critical because soil $\mathrm{N}$ concentration changes with soil water availability (Li et al., 2006; Ierna et al., 2011). Deficit irrigation or low soil humidity during the growing period reduces yields and increases accumulation of nitrates in soil that are leached away during the wet fall and winter periods, resulting in the highest leaching amounts with high fertilisation rates. The residual nitrate in soil profile increases as humidity in soil decreases and as fertilisation rates increase (Peralta and Stockle, 2001; Neumann et al., 2012). Plant biomass and tuber yield decrease almost proportionally to water consumption. $\mathrm{N}$ uptake is higher if irrigation or soil humidity is close to $100 \%$ of maximum evapotranspiration (Dalla Costa et al., 1997). However, high precipitation in summer may lead to significantly higher $\mathrm{P}$ and $\mathrm{N}$ leaching losses (Neumann et al., 2012).

Many factors and processes influence the relation between nitrogen uptake and nitrogen supply: initial amount of mineral $\mathrm{N}$, net mineralisation or immobilisation, denitrification, leaching, and atmospheric deposition. All factors that affect the depth of root penetration (density and texture of soil, $\mathrm{pH}$, etc.) or its function (including pests, diseases, drought and water logging) also affect the relationships between supply and uptake (Vos, 1997). Nutrient-use efficiency would be significantly improved with more root hairs per unit of root length, increased root growth longevity and density, and plants with greater rooting depth. This improvement alone would significantly reduce the potential impact of potato production on water and environmental quality parameters, and decrease the production costs. Nutrient-use efficiency might also be increased by improved nutrient utilisation within the plant via increased translocation or recycling. Development of plants with resistance to selected diseases could also change their nutritional requirements, as there are close associations between disease resistance and nutritional adequacy (Westerman, 2005).

Knowledge of the relationships between supply and uptake is essential in the framework of studies on environmental impact, and for developing recommendations for fertilizer supply (Vos, 1997). According to the European Commission on Nitrate Directive implementation in Latvia, maximum mineral fertiliser rates applied for crops as well as restrictions in mineral fertilisation use have to be set based on research results and conclusions (Ruza et al., 2011).

The aim of the current research was to investigate the efficiency of nitrogen fertiliser uptake for potato under different $\mathrm{N}$ fertiliser rates in growing conditions of Latvia.

\section{MATERIALS AND METHODS}

Design of experiment. The field trials were carried out at the State Priekul,i Plant Breeding Institute from 2009 till 2012. The trials were set up in fields with sod podzolic sandy loam soil. Soil acidity $\left(\mathrm{pH}_{\mathrm{KCl}}\right)$ varied from 5.0 to 6.0 in all three soil layers, which was suitable for potato growing (Table 1). The organic matter content in soil was within range of 11-27 $\mathrm{g} \mathrm{kg}^{-1}$; deeper in soil the content of organic matter was lower. The plant available phosphorus $\left(\mathrm{P}_{2} \mathrm{O}_{5}\right)$ and potassium $\left(\mathrm{K}_{2} \mathrm{O}\right)$ in soil was medium to high; especially high levels occurred in the year 2012. In deeper layers of soil, the concentrations of availabile nutrients decreased. Exchangeable magnesium $(\mathrm{Mg})$ in soil was medium each trial year. 
Table 1

SOIL PROPERTIES IN TRIAL FIELDS IN PRIEKUḶI. 2009-2012

\begin{tabular}{lcccccc}
\hline \multicolumn{1}{c}{ Parameters } & Soil layer & 2009 & 2010 & 2011 & 2012 \\
\hline $\mathrm{pH}_{\mathrm{KCl}}$ & $0-20 \mathrm{~cm}$ & 5.8 & 5.4 & 5.3 & 6.0 \\
& $20-40 \mathrm{~cm}$ & 5.4 & 5.2 & 5.4 & 5.9 \\
& $40-60 \mathrm{~cm}$ & 5.0 & 5.2 & 5.2 & 5.7 \\
\hline Organic matter, $^{-1}$ & $0-20 \mathrm{~cm}$ & 19 & 19 & 27 & 25 \\
$\mathrm{~g} \mathrm{~kg}^{-1}$ & $20-40 \mathrm{~cm}$ & 15 & 15 & 21 & 17 \\
& $40-60 \mathrm{~cm}$ & 11 & 11 & 17 & 13 \\
\hline $\mathrm{P}_{2} \mathrm{O}_{5}, \mathrm{mg} \mathrm{kg}^{-1}$ & $0-20 \mathrm{~cm}$ & 115 & 139 & 130 & 206 \\
& $20-40 \mathrm{~cm}$ & 93 & 87 & 65 & 134 \\
& $40-60 \mathrm{~cm}$ & 40 & 59 & 20 & 47 \\
\hline $\mathrm{K}_{2} \mathrm{O}, \mathrm{mg} \mathrm{kg}^{-1}$ & $0-20 \mathrm{~cm}$ & 93 & 181 & 120 & 189 \\
& $20-40 \mathrm{~cm}$ & 103 & 114 & 111 & 161 \\
& $40-60 \mathrm{~cm}$ & 68 & 122 & 96 & 153 \\
\hline $\mathrm{Mg}$ & $0-20 \mathrm{~cm}$ & 129 & 142 & 129 & 175 \\
& $20-40 \mathrm{~cm}$ & 110 & 101 & 117 & 135 \\
& $40-60 \mathrm{~cm}$ & 81 & 101 & 114 & 140
\end{tabular}

One-factor (rate of $\mathrm{N}$ fertiliser) field trials were conducted in four replications. Nine fertilisation variants were applied: without fertilisation; PK dose for a potato yield level of 40 $\mathrm{t} \mathrm{ha}^{-1}$; and seven variants with the PK dose plus increasing $\mathrm{N}$ fertilisation rate from 30 to $210 \mathrm{~kg} \mathrm{ha}^{-1}$. The $\mathrm{P}$ application doses were $60,60,80,100$, and $40 \mathrm{~kg} \mathrm{ha}^{-1}$, and $\mathrm{K}$ application doses were $110,110,150,200$, and $100 \mathrm{~kg} \mathrm{ha}^{-1}$ in the years 2008, 2009, 2010, 2011, and 2012, respectively.

Two potato varieties were included in the trial: early variety 'Borodjanskiy Rozoviy' (the Ukraine), and medium late variety 'Brasla' (Latvia).

Certified potato seed material was used. Seed tubers were planted in furrows; distance between furrows was $0.7 \mathrm{~m}$ and distance between tubers was $0.25 \mathrm{~m}$.

The potatoes were planted in the second week of May and harvested in the late days of August or beginning of September each trial year. Harrowing and ridging were performed once before germination followed by herbicide treatment. During the growing season, all necessary plant protection measures were performed. The haulm was cut ten days before harvesting.

The potato tuber yield was determined after harvesting. The tuber starch content was determined indirectly via specific gravity as percentage of fresh weight.

The taste of boiled tubers was assessed by an expert panel using a 9-point scale (9 - extremely liked; 1 - extremely disliked). Darkening of tuber flesh after boiling was assessed one hour after boiling using a 9-point scale (9 - no colour change; 1 - very dark colour).

The concentrations of nitrogen, phosphorus and potassium in potato tubers were determined by the standard methods ISO 5983-2:2005, ISO 6491:1998, and LVS EN ISO 6869:2002.
Nitrogen outcome was calculated based on total nitrogen content in tubers and foliage. Apparent recovery fraction (ARF) for nitrogen was calculated using the following equation (1) (Montemurro et al., 2007):

$A R F=\frac{\left(N_{x}-N_{c}\right)}{N_{d}}$,

where $\mathrm{N}_{\mathrm{x}}-\mathrm{N}$ uptake at $\mathrm{N}_{\mathrm{x}}, \mathrm{kg} \mathrm{ha}^{-1} ; \mathrm{N}_{\mathrm{c}}-\mathrm{N}$ uptake at control rate, $\mathrm{kg} \mathrm{ha}^{-1} ; \mathrm{N}_{\mathrm{d}}$ - rate of nitrogen, $\mathrm{kg} \mathrm{ha}^{-1}$.

Significance of the differences $\left(\mathrm{LSD}_{0.05}\right)$ among the yields was assessed using one-way ANOVA.

Weather conditions. In 2009, potato germination was delayed for a week because of wet soil after heavy rainfalls at the beginning of June. The average air temperature exceeded long-term data by $0.5-0.7{ }^{\circ} \mathrm{C}$ in May and June. Later in the season, average air temperature and precipitation were similar to long-term averages: average daily temperature varied from $14.1{ }^{\circ} \mathrm{C}$ to $17.2{ }^{\circ} \mathrm{C}$, and precipitation from $2.6 \mathrm{~mm}$ to $58.1 \mathrm{~mm}$ in ten days. The weather conditions were acceptable for favourable potato yield development.

In the following two years, the weather conditions were considerably warmer, with heavy rainfalls occasionally. In 2010 , compared to 2011, the beginning of the potato growing period was slightly warmer, with average air temperature $2.1{ }^{\circ} \mathrm{C}$ and $0.6{ }^{\circ} \mathrm{C}$ higher than the long-term averages in those years, respectively. The weather was hot and dry in June 2011, and the precipitation reached only $46 \%$ of longterm level. In 2010, the air temperature in the second part of vegetation period was $3-5^{\circ} \mathrm{C}$ higher than the long-term average.

During 2011, the air temperature was similar to long-term data. In 2010, rainfalls were heavy and precipitation exceeded the long-term average by 24-31\%. In 2011, July was dry and precipitation was only $85 \%$ of the long-term level, whereas in the second decade of August precipitation exceeded the long-term average by $109 \%$. Some late blight damage was observed in 2010 , because of the dry and warm weather conditions, which were unfavourable for disease development. In 2011, the infection of late blight started in mid-August, when potato tubers mostly were developed.

At the beginning of the growing period in the third decade of May 2012, the soil was extremely wet because of heavy precipitation (2.5 times higher than long-term level). The heavy and wet soil was the reason for delayed sprouting compared to the previous two warmer years. In July 2012, precipitation was high (157\% of the long-term level, and the average daily temperature reached $18.1^{\circ} \mathrm{C}$. In August, frequent rainfalls persisted, causing high air and soil humidity.

\section{RESULTS}

Potato tuber yields depended, to a great extent, on meteorological conditions in individual years and on the specific 


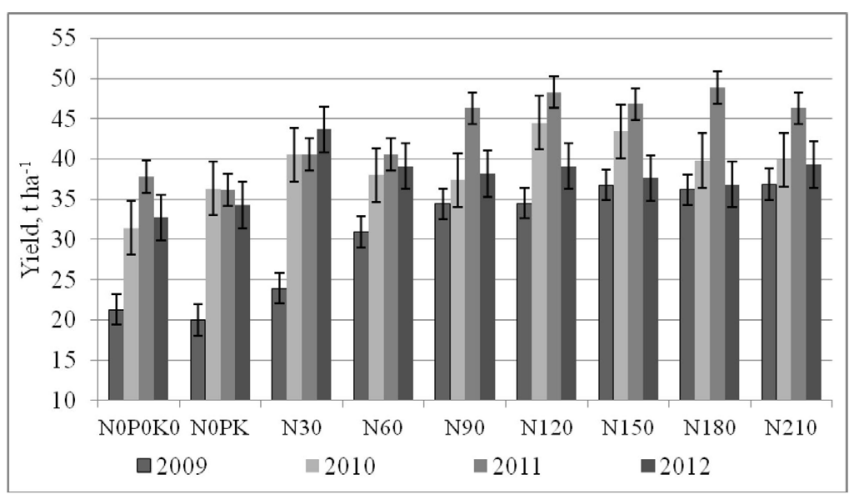

Fig. 1. Yield of potato variety 'Brasla' depending on year and $\mathrm{N}$ fertilisation.

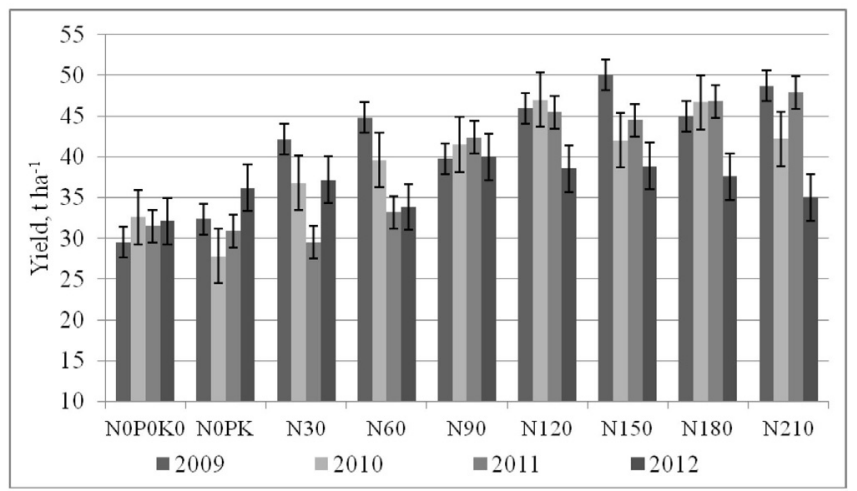

Fig. 2. Yield of potato variety 'Borodjanskiy Rozoviy' depending on year and $\mathrm{N}$ fertilisation.

features of the variety. The potato variety 'Brasla' had the lowest tuber yield in 2009 (Fig. 1). Tuber yields increased with nitrogen fertiliser rate up to $\mathrm{N}_{90}\left(\mathrm{LSD}_{0.05}=3.8\right)$. A further increase in nitrogen fertiliser rate did not significantly increase yield, although a trend was visible up to N150. Tuber yield for potato variety 'Borodjanskiy Rozoviy' was considerably higher in 2009 and increased significantly with nitrogen fertiliser rate up to N150 (Fig. 2). A further increase in nitrogen fertiliser rate had a negative impact on the potato tuber yield.

The year 2012 was not particularly favourable for potato production. Both investigated potato varieties produced similar medium-high tuber yields of 38-39 $\mathrm{t} \mathrm{ha}^{-1}$. A significant relationship between nitrogen fertiliser rate and tuber yield was not observed in that year.

The four-year average yields differed less between both potato varieties, and the highest tuber yield was found with nitrogen fertiliser rate N120 (Fig. 3). Further increase in nitrogen fertiliser rates had no significant impact on tuber yield. According to the four-year average tuber yield for the potato varieties, the tuber yield increased in $92 \%$ of cases with raised nitrogen fertiliser rate.

Culinary traits, such as darkening of tuber flesh and taste after boiling, are important for potato produced for market and catering. According to the four-year average levels, phosphorus and potash fertilisers did not cause tuber flesh darkening after boiling. In treatments NOPOKO and NOPK,

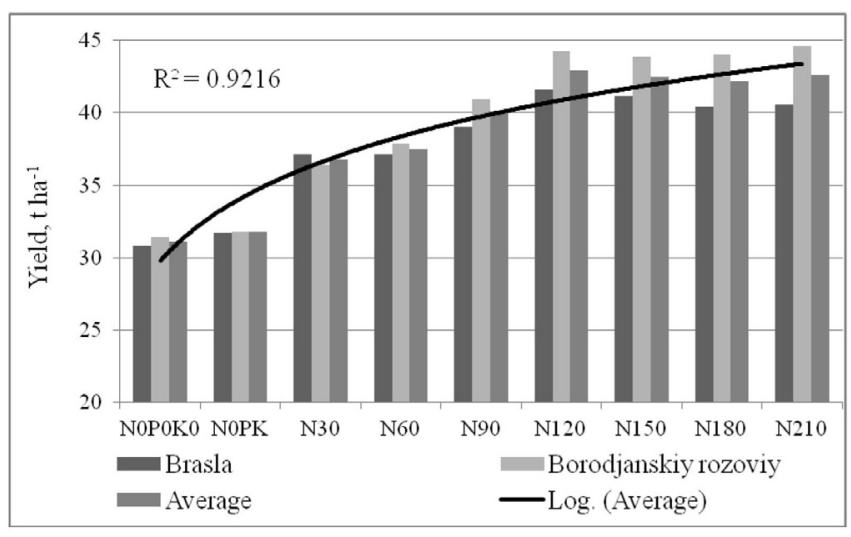

Fig. 3. Average yield of potato tubers depending on variety and fertilisation.

Table 2

CULINARY TRAITS OF POTATO TUBERS DEPENDING ON NITROGEN FERTILISATION, AVERAGE 2009-2012

\begin{tabular}{l|cc|c|c}
\hline \multirow{2}{*}{ Treatment } & \multicolumn{2}{c|}{$\begin{array}{c}\text { Tuber flesh darkening after } \\
\text { boiling (points, 1-9) }\end{array}$} & \multicolumn{2}{c}{ Taste (points, 1-9) } \\
\cline { 2 - 5 } & Brasla & $\begin{array}{c}\text { Borodjanskiy } \\
\text { Rozoviy }\end{array}$ & Brasla & $\begin{array}{c}\text { Borodjanskiy } \\
\text { Rozoviy }\end{array}$ \\
\hline $\mathrm{N}_{0} \mathrm{P}_{0} \mathrm{~K}_{0}$ & 7 & 7 & 7.6 & 7.6 \\
$\mathrm{~N}_{0} \mathrm{PK}$ & 7 & 7 & 7.5 & 7.4 \\
$\mathrm{~N}_{30}$ & 6 & 8 & 7.4 & 7.4 \\
$\mathrm{~N}_{60}$ & 6 & 7 & 7.0 & 7.0 \\
$\mathrm{~N}_{90}$ & 5 & 6 & 7.1 & 6.6 \\
$\mathrm{~N}_{120}$ & 5 & 6 & 6.9 & 6.3 \\
$\mathrm{~N}_{150}$ & 5 & 6 & 6.6 & 7.2 \\
$\mathrm{~N}_{180}$ & 5 & 5 & 6.6 & 6.8 \\
$\mathrm{~N}_{210}$ & 4 & 5 & 6.5 & 6.4
\end{tabular}

tuber flesh darkening after boiling, both potato varieties were given a score of 7 (Table 2). However, for 'Brasla', already with the first nitrogen fertiliser rate N30 applied, tuber flesh darkening after boiling was assessed as one point lower than for 'Borodjanskiy Rozoviy', and in treatment N210 Brasla had a score of only 4 points. For the potato variety 'Borodjanskiy Rozoviy', tuber flesh darkening, compared to the standard fertiliser dose, was found only starting with fertiliser rate $\mathrm{N} 90$, and tubers obtained from treatment N210 received the lowest assessment -5 points.

Taste of boiled tubers also slightly changed with nitrogen fertiliser rate. Increasing nitrogen fertiliser rate from N0 to N210 lowered the tuber taste assessment from 7.5 points by one point.

Starch concentration in tubers and starch yield obtained from an area unit are important indices for potatoes processed into starch. The starch concentration of variety 'Brasla' was comparatively higher than of the variety 'Borodjanskiy Rozoviy'. The highest starch concentration , four-year average $17.4 \%$, was found in the non-fertilised (NOPOK0) treatment (Fig. 4). With increased nitrogen fertiliser rate, starch concentration in tubers decreased, to $15.4 \%$ in treatment N210. For the potato variety 'Borodjanskiy 


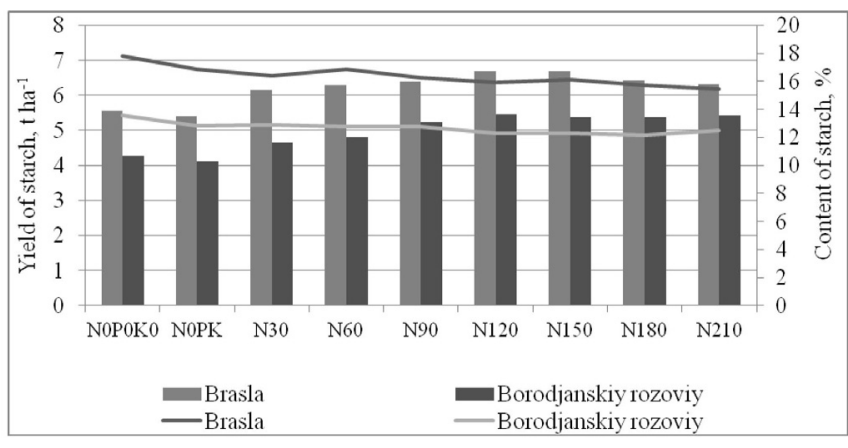

Fig. 4. Concentration and yield of starch depending on nitrogen fertilisation rate.

Rozoviy', tuber starch concentration was considerably lower and, although increased nitrogen fertiliser rates reduced tuber starch concentration also for this potato variety, the decrease in starch concentration was considerably lower. The difference between the highest and the lowest values was $1.4 \%$ for 'Borodjanskiy Rozoviy' and $2.4 \%$ for 'Brasla'.

Starch yield per area unit depends on the potato tuber yield and tuber starch content. Overall, the four-year averages were higher for the potato variety 'Brasla' than those for variety 'Borodjanskiy Rozoviy'. Starch yield per area unit increased from $5.4 \mathrm{t} \mathrm{ha}^{-1}$ ('Brasla') and $4.1 \mathrm{t} \mathrm{ha}^{-1}$ ('Borodjanskiy Rozoviy') in treatment NOPK to 6.7 and $5.45 \mathrm{t} \mathrm{ha}^{-1}$ in treatment N120, respectively. The increase of starch yield for both potato varieties was due to an increase of tuber yield, and thus the highest yield was with a fertiliser rate of N120. Since a further increase in nitrogen fertiliser rate did not affect the yield significantly and tuber starch content continued to decrease, starch yield with higher fertilisation levels was lower.

Plant photosynthetic area is of great importance for yield production, and in potato plantings can be estimated as foliage mass per area unit. On the average for the four experiment years, an increase of nitrogen fertiliser rate up to N150 resulted in an increase in foliage mass per area unit (Fig. 5). The ratio of foliage to tuber mass increased from 0.40 in treatment NOP0K0 to 0.85 in treatment N150. A further increase in the nitrogen fertiliser rate above N150 did not cause significant changes in foliage mass per area unit nor in proportion to tuber mass. Logarithmic regression analysis suggested that quantity of the potato leaf mass is affected mainly by the nitrogen fertiliser amount.

Leaf and stem mass also is an important user of nutrients. Yield of the tuber associated with the amount of nutrients necessary for foliage production.

Tuber nitrogen concentration increased with nitrogen fertiliser from $1.09 \%$ in treatment NOPK up to $1.53 \%$ in treatment N120 and practically remained constant in subsequent nitrogen fertiliser treatments (Fig. 6). The nitrogen concentration in potato foliage was twice as high as that in tubers and continuously increased with nitrogen fertiliser rate, and particularly at the high rates (N150-210).

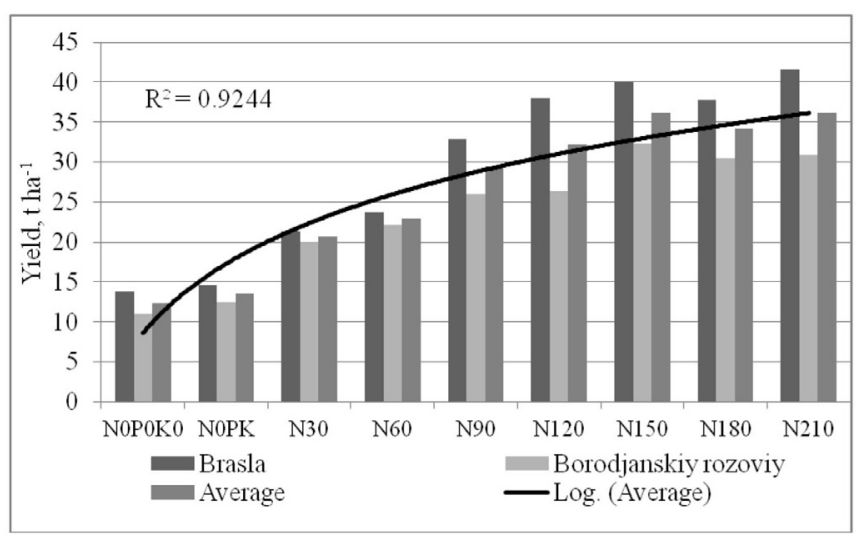

Fig. 5. Foliage yield depending on nitrogen fertilisation rate, average 2009-2012.

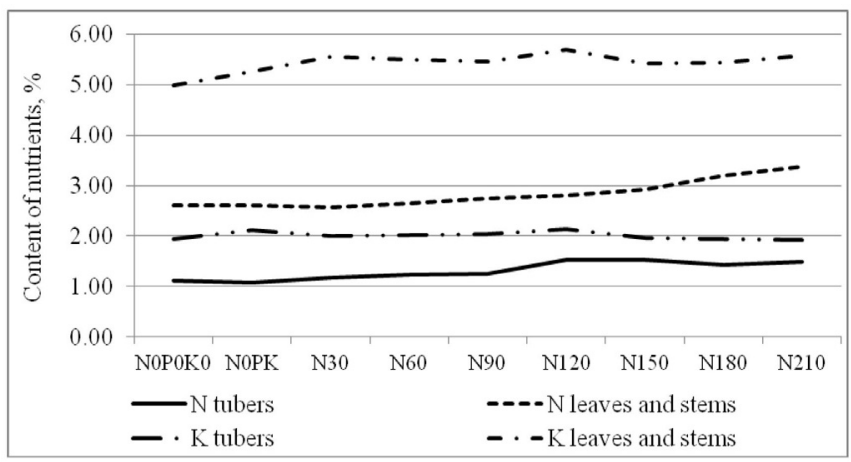

Fig. 6. Concentration of nitrogen and potassium in potato tubers and foliage depending on fertilizer fertilisation rate.

Phosphorus concentration in potato tubers and foliage was similar $0.20-0.24 \%$ not dependent on nitrogen fertiliser rate.

Potassium concentration in tubers was almost similar for both potato varieties and rather constant irrespective of meteorological conditions in each year and $\mathrm{N}$ fertiliser rate. However, a tendency towards an insignificant decline in potassium concentration in tubers was observed when higher nitrogen fertiliser rates (N150-N210) were applied. Potassium concentration in foliage was 2.5-3 times higher compared content in tubers. A close correlation was not established between tuber potassium concentration and nitrogen fertiliser rate. Potassium concentration in foliage was more affected by weather conditions in the vegetation period.

Nutrient removal with potato yield increased with increasing nitrogen fertiliser rate (Table 3).

Tuber nitrogen uptake increased by $73 \%$ under the influence of nitrogen fertiliser. However, total amount of nitrogen taken up with tubers and foliage increased more than twice: from $123 \mathrm{~kg} \mathrm{ha}^{-1}$ in treatment NOPK up to $278 \mathrm{~kg}$ $\mathrm{ha}^{-1}$ in treatment N210PK. Similarly, total $\mathrm{K}_{2} \mathrm{O}$ removal increased from $266 \mathrm{~kg} \mathrm{ha}^{-1}$ in treatment NOP0K0 up to $485 \mathrm{~kg}$ $\mathrm{ha}^{-1}$ in treatment N150PK. Also total P2O5 removal increased under the influence of nitrogen fertiliser; however, this increase was not as strong. 
PLANT NUTRIENT UPTAKE BY YIELD, KG HA ${ }^{-1}$ AND APPARENT RECOVERY

\begin{tabular}{|c|c|c|c|c|c|c|c|c|}
\hline \multirow[t]{2}{*}{ Treatment } & \multicolumn{4}{|c|}{ Uptake by yield, $\mathrm{kg} \mathrm{ha}^{-1}$} & \multicolumn{4}{|c|}{ Apparent recovery } \\
\hline & $\mathrm{N}$ by tubers & $\begin{array}{c}\mathrm{N} \text { by tubers and } \\
\text { foliage }\end{array}$ & $\begin{array}{c}\mathrm{P}_{2} \mathrm{O}_{5} \text { by tubers } \\
\text { and foliage }\end{array}$ & $\begin{array}{c}\mathrm{K}_{2} \mathrm{O} \text { by tubers } \\
\text { and foliage }\end{array}$ & $\mathrm{N}$ by tubers & $\begin{array}{c}\mathrm{N} \text { by tubers and } \\
\text { foliage }\end{array}$ & $\begin{array}{c}\mathrm{P}_{2} \mathrm{O}_{5} \text { by tubers } \\
\text { and foliage }\end{array}$ & $\begin{array}{c}\mathrm{K}_{2} \mathrm{O} \text { by tubers } \\
\text { and foliage }\end{array}$ \\
\hline $\mathrm{N}_{0} \mathrm{P}_{0} \mathrm{~K}_{0}$ & 83.8 & 123.5 & 42.9 & 266.5 & $\mathrm{x}$ & $\mathrm{x}$ & $\mathrm{X}$ & $\mathrm{x}$ \\
\hline $\mathrm{N}_{0} \mathrm{PK}$ & 82.8 & 123.2 & 41.9 & 283.0 & $\mathrm{x}$ & $\mathrm{X}$ & 0.01 & 0.19 \\
\hline $\mathrm{N}_{30}$ & 103.0 & 162.4 & 48.2 & 369.7 & 0.67 & 1.51 & 0.15 & 1.05 \\
\hline $\mathrm{N}_{60}$ & 111.9 & 180.1 & 50.7 & 388.3 & 0.49 & 1.05 & 0.16 & 1.13 \\
\hline $\mathrm{N}_{90}$ & 121.1 & 219.6 & 54.6 & 462.8 & 0.43 & 1.14 & 0.27 & 1.83 \\
\hline $\mathrm{N}_{120}$ & 157.5 & 246.5 & 58.0 & 471.7 & 0.62 & 1.08 & 0.27 & 1.86 \\
\hline $\mathrm{N}_{150}$ & 156.3 & 281.9 & 67.1 & 485.5 & 0.49 & 1.10 & 0.44 & 1.92 \\
\hline $\mathrm{N}_{180}$ & 144.4 & 253.7 & 54.7 & 460.3 & 0.34 & 0.76 & 0.20 & 1.65 \\
\hline $\mathrm{N}_{210}$ & 153.0 & 278.1 & 54.3 & 467.9 & 0.33 & 0.77 & 0.20 & 1.88 \\
\hline
\end{tabular}

\section{DISCUSSION}

The results for the four trials years suggest that an increase in nitrogen fertiliser rate up to $\mathrm{N} 120 \mathrm{~kg} \mathrm{ha}^{-1}$ improved potato yield. A further increase in nitrogen fertiliser rate caused a significant increase in tuber yield only when meteorological conditions were particularly favourable. Similar results were obtained also in the Czech Republic, where a nitrogen fertiliser rate of N140 is recommended (Srek et al., 2010).

Nitrogen fertiliser rates should be differentiated, depending on the produced potato variety and commercial use of the potato tuber. Potatoes for market and catering produced with nitrogen fertiliser rates above N150 have risk of the tuber flesh darkening after boiling and decreased taste quality of boiled tuber. Starch concentration in tubers and starch yield per area unit are the most important parameters for potato starch processing. In cases of insignificant yield differences between potato varieties, production of potato varieties higher in starch content is more profitable. This is the case for potato variety 'Brasla', which had higher starch yield per area unit although the obtained tuber yield was somewhat lower. Nitrogen fertiliser rates above N120-150 did not result in an increase of starch yield. Other studies have shown that starch concentration slightly decreased with increased $\mathrm{N}$ and $\mathrm{P}$ level after fertilisation, although the effects were not statistically significant (Ozturk et al., 2010).

Tuber nitrogen concentration slightly increased with nitrogen fertiliser rate up to rate N120; further increase in nitrogen rate did not affect the nitrogen concentration in tubers. Other studies suggest that under the influence of different external conditions, total nitrogen removal is about $29-72 \%$ of the nitrogen fertiliser rate (Darwish et al., 2006; Li et al., 2006). Foliage nitrogen concentration considerably increased with nitrogen fertiliser rate above N120. Consequently, nitrogen total removal was directly associated with increase in potato tuber yield related to an increase in nitrogen fertiliser rate up to N120, as only an insignificant increase in $\mathrm{N}$ concentration in tubers was observed. Total nitrogen removal (tubers and foliage) was directly associated with an increase in the proportional mass of foliage. Nitrogen fertiliser rates above N120 slightly increased concentration of nitrogen in foliage. Literature suggests that nitrogen removal is higher if irrigation or soil moisture is close to $100 \%$ of soil water-holding capacity (Dalla Costa $e t$ al., 1997). In our case, this was true if the total, i.e. tuber and foliage, mass was considered, as foliage mass and concentration of nitrogen increased with precipitation. However, abundant precipitation in summer favours significantly higher leaching and losses of $\mathrm{P}$ and $\mathrm{N}$ (Neumann et al., 2012).

Changes in $\mathrm{P}_{2} \mathrm{O}_{5}$ utilisation indices are not high and generally are associated only with yield changes under the influence of fertiliser rates.

Since tuber potassium concentration practically did not depend on nitrogen fertiliser rate, the potassium removal with yield depended only on the obtained yield. However, total potassium utilisation was mainly dependent on potato foliage mass, as potassium concentration in foliage was considerably higher than in tubers. Since foliage mass and its relative proportion in the total yield increased with each successive nitrogen fertiliser step, the total potassium removal also increased.

Agronomic efficiency of nutrient utilisation is greatly dependent on meteorological conditions. However, in fertiliser normative planning, the average indices up to a certain limit of fertiliser rates that provide the most rational utilisation of nutrients should be considered. Further additional corrections for fertiliser rates should be made depending on meteorological conditions in the vegetation period. In most studies and also in practice, nutrient utilisation indices mainly referred to the basic product. Referring nitrogen fertiliser utilisation only to tuber yield, the $\mathrm{N}$ utilisation coefficient from mineral fertiliser up to nitrogen fertiliser rate N120 on average 0.60 . Further increase in nitrogen rate with each successive step reduced the $\mathrm{N}$ utilisation coefficient, which was only 0.33 in treatment N210. Results from other studies also confirm linear reduction of agronomic $\mathrm{N}$ efficiency with increased $\mathrm{N}$ rate (Darwish et al., 2006; Kumar et al., 2007; Fontes et al., 2010). 
In order for any plant to produce the main utilisable part of the yield, nutrients are utilized for production of the entire plant, including photosynthetic parts. In calculation of nutrient turnover in time, it should be considered, of course, that potato foliage will be included in the subsequent turnover of total nutrients. In order for a plant to produce the expected yield, initial nutrient supply is required for plant vegetative mass formation and subsequently for economically substantial yield production. Nitrogen fertiliser, obviously, promotes soil nitrification processes as well as potassium uptake from soil nutrient stock. In most cases, when nutrient utilisation is calculated (Montemurro et al., 2007), nutrient utilisation indices exceed the incorporated fertiliser amount considerably. In our study, an increase in nitrogen fertiliser rate from $\mathrm{N} 30$ up to $\mathrm{N} 210$ resulted in decline of the $\mathrm{N}$ utilisation coefficient from 1.51 to 0.77 but increase of the potassium utilisation coefficient from 1.05 up to 1.88 .

Producing sufficiently high and stable yields under Latvia conditions by performing crop management corresponding to variety requirements, the needed nitrogen fertiliser rate is N120; however, depending on the character of the vegetation period and top-dressing applied, this rate can be increased up to N150. In planning of nutrient sufficiency balance, both basic product yield and amount of total biological mass should be considered.

\section{ACKNOWLEDGEMENTS}

This study was supported by the grant of the Ministry of Agriculture of the Republic of Latvia "Determination of maximal fertiliser norms for crops".

\section{REFERENCES}

Anonīms (2011). Latvijas lauksaimniecība 2011 [Agriculture in Latvia 2011]. Latvijas Republikas Zemkopības ministrija. Retrieved 20 February 2013, from http://www.zm.gov.lv/doc_upl/LS_2012.pdf (in Latvian).

Baniuniene, A., Zekaite, V. (2008). The effect of mineral and organic fertilizers on potato tuber yield and quality. Latv. J. Agron., 11, 202-206.

Dalla Costa, L., Delle Vedove, G., Gianquinto, G., Giovanardi, R., Peressotti, A. (1997). Yield, water use efficiency and nitrogen uptake in potato: Influence of drought stress. Potato Res., 40, 19-34.

Darwish, T. M., Atallah, T. W., Hajhasan, S., Haidar, A. (2006). Nitrogen and water use efficiency of fertigated processing potato. Agr. Water Manag., 85, 95-104.
Fontes, P. C. R., Braun, H., Bussato, C., Cecon, P. R. (2010). Economic optimum nitrogen fertilization rates and nitrogen fertilization rate effects on tuber characteristics of potato cultivars. Potato Res., 53, 167-179.

Goffart, J. P., Olivier, M., Frankinet, M. (2008). Potato crop nitrogen status assessment to improve $\mathrm{N}$ fertilization management and efficiency: Past present - future. Potato Res., 51, 355-383.

Ierna, A., Pandino, G., Lombardo, S., Mauromicale, G. (2011). Tuber yield, water and fertilizer productivity in early potato as affected by a combination of irrigation and fertilization. Agr. Water Manag., 101, 35-41.

Kumar, P., Pandey, S. K., Singh, B. P., Singh, S. V., Kumar, D. (2007) Effect of nitrogen rate on growth, yield, economics and crisps quality of Indian potato processing cultivars. Potato Res., 50, 143-155.

Li, H., Parent, L. E., Karam, A. (2006). Simulation modelling of soil and plant nitrogen use in a potato cropping system in the humid and cool environment. Agr. Ecosys. Environ., 115, 248-260.

Montemurro, F., Convertini, G., Ferri, D. (2007). Nitrogen application in winter wheat grown in Mediterranean Conditions: Effects on nitrogen uptake, utilization efficiency, and soil nitrogen deficit. J. Plant Nutr., 30 (10), 1681-1703.

Moreno, A., Moreno, M. M., Ribas, F., Cabello, M. J. (2003). Influence of nitrogen fertilizer on grain yield of barley (Hordeum vulgare L.) under irrigated conditions. Spanish J. Agr. Res., 1 (1), 91-100.

Neumann, A., Torstensson, G., Aronsson, H. (2012). Nitrogen and phosphorus leaching losses from potatoes with different harvest times and following crops. Field Crop Res., 133, 130-138.

Oztrurk, E., Kavurmaci, Z., Kara, K., Polat, T. (2010). The effect of different nitrogen and phosphorus rates on some quality traits of potato. Potato Res., 53, 309-312.

Peralta, J. M., Stockle, C. O. (2001). Dynamics of nitrate leaching under irrigated potato rotation in Washington State: A long-term simulation study. Agr. Ecosyst. Environ., 88, 23-34.

Ruza, A., Kreita, Dz., Katamadze, M. (2011). Mineral fertilizer use efficiency in spring barley sowings. AGRAARTEADUS / J. Agr. Sci., 22 (2), 40-44.

Srek, P., Hejcman, M., Kunzova, E. (2010). Multivariate analysis of relationship between potato (Solanum tuberosum L.) yield, amount of applied elements, their concentrations in tubers and uptake in a long-term fertilizer experiment. Field Crop Res., 118, 183-193.

Vos, J. (2009). Nitrogen responses and nitrogen management in potato. Potato Res., 52, 305-317.

Vos, J. (1997). The nitrogen response of potato (Solanum tuberosum L.) in the field: Nitrogen uptake and yield, harvest index and nitrogen concentration. Potato Res., 40, 237-248.

Vos, J. (1995). The effects of nitrogen supply and stem density on leaf attributes and stem branching in potato (Solanum tuberosum L.). Potato Res., 38 , 271-279.

Westerman, D. T. (2005). Nutritional requirements of potatoes. Ame. J. Potato Res., 82, 301-307.

Received 18 March 2013

\section{SLĀPEKḶA IETEME UZ KARTUPEL̨U PRODUKTIVITĀTI UN BARĪBAS VIELU IZMANTOŠANAS EFEKTIVITĀTI}

Lauka izmēǵinājumi tika iekārtoti Valsts Priekuḷu laukaugu selekcijas institūtā laikā no 2009. gada līdz 2012. gadam ar divām kartupeḷu šḳirnēm 'Brasla' un 'Borodjanskij Rozovij' četros atkārtojumos ar deviniem mēslojuma variantiem: NOP0K0 — kontrole (bez mēslojuma), N0PK - PK mēslojums turpmākajos N variantos vienāds, N30PK, N60PK, N90PK, N120PK, N150PK, N180PK, N210PK. Fosfora un kālija mēslojuma daudzums katru gadu noteikts atbilstoši šo barības vielu saturam augsnē konkrētā laukā noteiktam ražas līmenim.

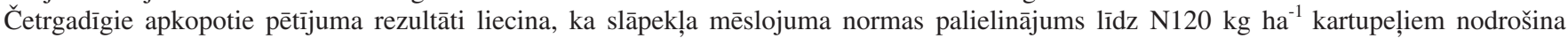
stabili nozīmīgu ražas pieaugumu. Tālāka slāpekḷa mēslojuma normas palielināšana tikai atsevišḳos meteoroloğiski labvēlīgos veǵetācijas apstākḷos veicina būtisku bumbuḷu ražas pieaugumu. Slāpekḷa kopējā iznesa ir tieši saistīta ar kartupeḷu bumbuḷu ražas palielināšanos līdz slāpekḷa mēslojuma normai N120 un tikai nelielam N satura pieaugumam bumbuḷos, bet kopējā slāpekḷa iznesa (bumbuḷi + laksti) jau tieši saistîti ar lakstu īpatsvara pieaugumu kopējā ražas masā un virs slāpekḷa mēslojuma normas — N120 ar slāpekḷa satura palielināšanos lakstos. 